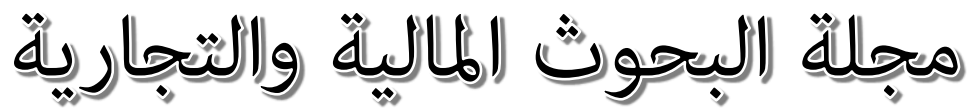

$$
\begin{aligned}
& \text { المجلد (21) - العدد الرابع - أكتوبر } 2020
\end{aligned}
$$

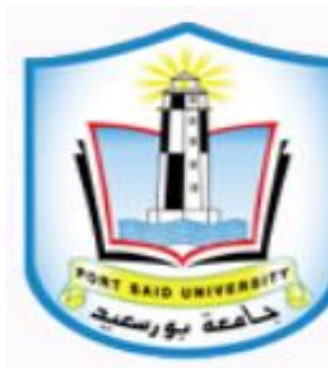

\title{
Analysis of Trade Relations between Egypt and the Nile Basin Countries Using the Gravity Model
}

\author{
تحليل العلاقات التجارية بين مصر ودول حوض النيل باستخدام نموذج \\ الجاذبية
}

\author{
Dr. Sally Mohamed Farid Mahmoud \\ Associate Professor of Economics, Department of Politics and \\ Economics, \\ Faculty of African postgraduate Studies, Cairo University \\ Tel. :(002) 01222944442 \\ Email: sallyfarid2000@yahoo.com,
}




\begin{abstract}
The study aims to analyze the trade relations between Egypt and the Nile Basin countries, using the econometric method by gravity model to measure the determinants of trade intensity between Egypt and the Nile Basin countries during the period (2000-2018). The study also relies on the environmental analysis to determine the strengths, weaknesses, opportunities, and threats of Egyptian trade relations with the Nile Basin countries. The study indicates that there is a positive relationship between the gross domestic product of Egypt and the Nile Basin countries with the trade intensity index between Egypt and the Nile Basin countries. The study concludes that there is a gap between the actual trade between Egypt and the Nile Basin countries and the hopes placed on it, and for reducing this gap requires more efforts. The intra-trade must be supported and strengthened through the development of infrastructure in the fields of transportation, energy, communications, and information technology, as well as increased coordination between Nile Basin Countries to unify the regulations and rules governing the movement of trade.
\end{abstract}

Keywords: Trade Relations, Egypt, Nile Basin Countries, and the Gravity Model. 


\section{Introduction}

The Nile Basin countries represent strategic importance for Egypt, where participation in the Nile water is one of its sources for linking common interests in the sense of maximizing the benefit of Egypt and the Nile Basin countries from trade relations and establishing projects that achieve this benefit.

The research problem is what are determinants of the trade relations between Egypt and the Nile Basin countries? And how Egypt using these determinants can maximize the benefit of the relations with the Nile basin countries?

The study aims to analyze the trade between Egypt and the Nile Basin countries, so the study focuses on the Nile Basin countries as Sudan, Eretria, Ethiopia, Uganda, Congo, Kenya, Tanzania, Rwanda, Burundi, and the data about South Sudan is not available.

The study uses the econometric method by the gravity model to measure the determinants of trade intensity between Egypt and the Nile Basin countries. The method measures trade intensity using the gravity model after describing it with real variables during the period (2000-2018), according to the model presented by Hanink and Owusu, The study also relies on the SWOT analysis to determine the strengths, weaknesses, opportunities, and threats of Egyptian trade relations with the Nile Basin countries.

The study is divided into the following five parts:

First: Literatures Review

Second: the Bilateral Trade Relations between Egypt and the Nile Basin

Countries

Third: the Economic Indicators on Trade between Egypt and the Nile Basin Countries

Fourth: Measuring Determinants of Trade Intensity between Egypt and the Nile Basin Countries

Fifth: SWOT Analysis (Strengths, Weaknesses, Opportunities, and Threats) Sixth: Policies for Activating the Egyptian Trade in the Nile Basin

\section{First: Literatures Review}

The study of (Marchand, et al 1999) is considered one of the most important studies presented in the trade relation field which focused on the results of two workshops in Amsterdam 1997 and Oslo 1998. ${ }^{1}$ The Study of (Jovanovic, 1998) focused on the effect of the integrative process not only in the field of trade creation but must be in an integrated way for an integrated set of elements. ${ }^{2}$ 
The study of (Pomfret, 1997), focused on the fact that regional trade arrangements must take into account the conditions of globalization in addition to focusing on the importance of transferring foreign investments and realizing benefits at the global level. ${ }^{3}$

The study of (Shaw, 1995) found that there are conditions other than encouraging freedom of trade, those conditions as to security, civil society organizations, and multinational companies, and their role in trade movement, so the new region must be studied with an integrated multivision. $^{4}$

The Study of (Robson, 1998), concerned with the economics of international integration and the impact of a free trade area on the market of two countries that produce the same product, and it was assumed the similarity of the demand function in both countries. The study concluded that there was a structural effect of the trade process between the two countries. ${ }^{5}$

Study of (Lahham et al, 2011) focused on the vision of Egypt and countries of the Nile Basin 2030, by analyzing Egypt's vision in economic, social, political, and water cooperation with countries of the Nile Basin using the Delphi method, the study concluded that Egypt should implement development projects in the Nile Basin countries and cooperate with international organizations. ${ }^{6}$

The study of (Ezzat and Abd Elkrim, 2013) presented the economic resources available for economic development in countries of the Nile Basin and the possibility of cooperation between them. The study concluded that development needs must be to establish relations and cooperation between the basin countries by using the human development guide and some social and development indicators and also reached a number of the most important mechanisms of cooperation in developing trade between the basin countries. In addition to the necessity of establishing rational management of the water resource in a way that realizes the political and economic interests and participates in trade and investment between the Nile Basin countries. ${ }^{7}$

The study of (Abd Eltawab and Mehana, 2016) measured the efficiency of Egyptian total foreign and agricultural trade with the Nile Basin countries and their determinants. The study concluded that countries of The Nile Basin represent the strategic importance of Egypt by its participation in the Nile water, so it is important to enhance Egypt's role with the Basin countries by increasing the presence of Egyptian products and stimulating trade exchange between Egypt and the Nile Basin countries. The study indicated the share of Egyptian agricultural trade amounted to about 99,4\% of the Egyptian foreign trade with the Nile Basin countries in 2013. ${ }^{8}$ 


\section{Second: the Bilateral Trade Relations between Egypt and the Nile Basin Countries}

The next figures analyze the bilateral trade relations between Egypt and the Nile Basin countries as follows:-

Figure (1) Exports and Imports of Egypt with the Nile Basin Countries during the Period (2000 - 2018)

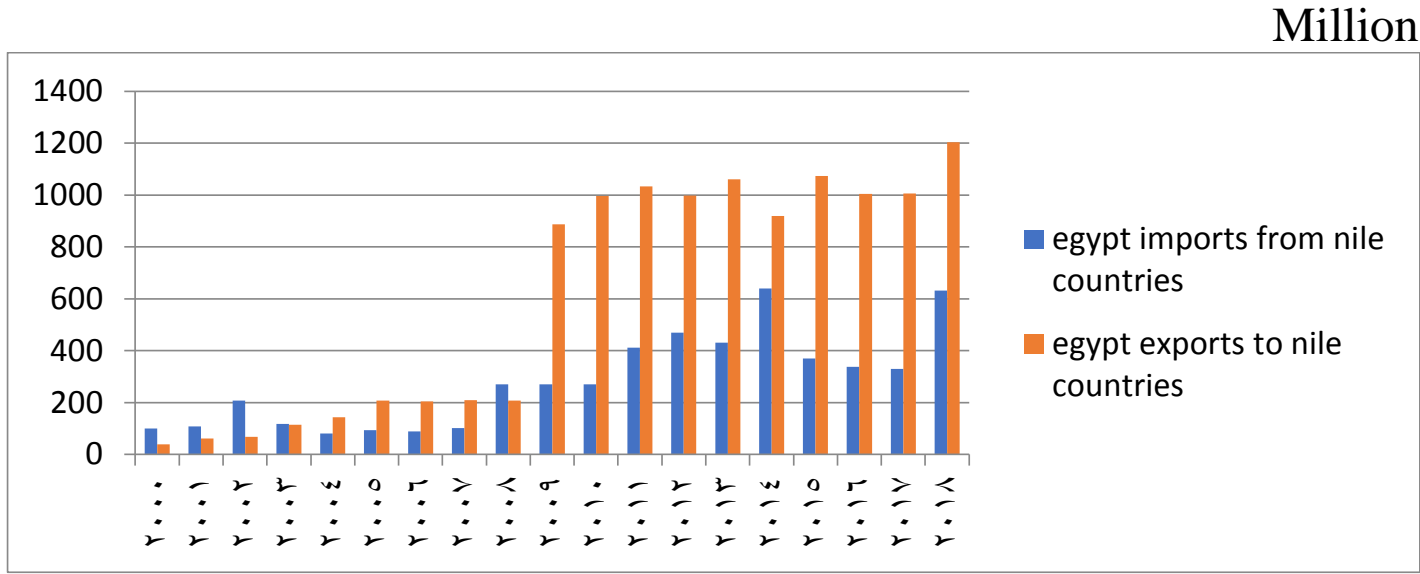

Source: by the author using data of Central Agency for Public Mobilization and Statistics Database, CAPMAS https://www.capmas.gov.eg,

Figure (1) shows the exports and imports of Egypt with the Nile Basin countries increased during the Period (2000 - 2018), the exports increased from 39 million $\$$ at 2000 to 1204 million $\$$ at 2018, and the imports increased from 100 million \$ at 2000 to 632 million \$ at 2018.

Figure (2) Relative Distribution of Egypt's Exports and Imports to the Nile Basin Countries in 2016, 2017

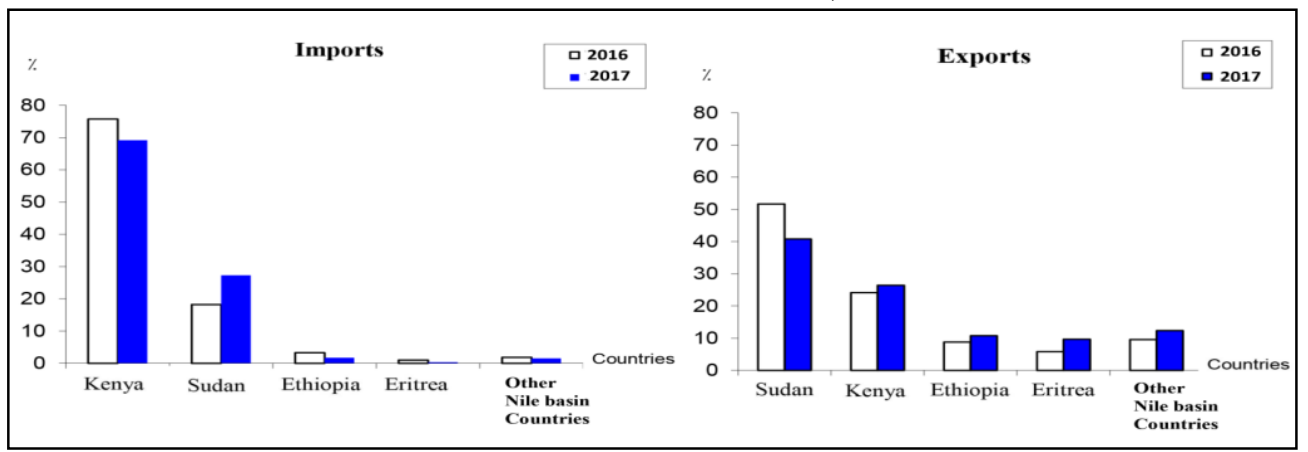

Source: Central Agency for Public Mobilization \& Statistics (2018). Annual Bulletin of Trade Exchange between Egypt \& Nile Basin Countries 2017, CAPMAS, October.

Figure (2) shows the relative distribution of Egypt's exports and imports to the Nile Basin countries, Kenya had 68\% of Egypt's imports from the Nile Basin countries in 2017, and then Sudan had 28\%. Also, Sudan had $40 \%$ of Egypt's Exports the Nile Basin countries in 2017, and then Kenya had about 25\%, Ethiopia 10\%, Eritrea $10 \%$. 
Figure (3) Relative Distribution of Egypt's Exports and Imports to the Nile Basin Countries According to Commodity Groups in 2016, 2017

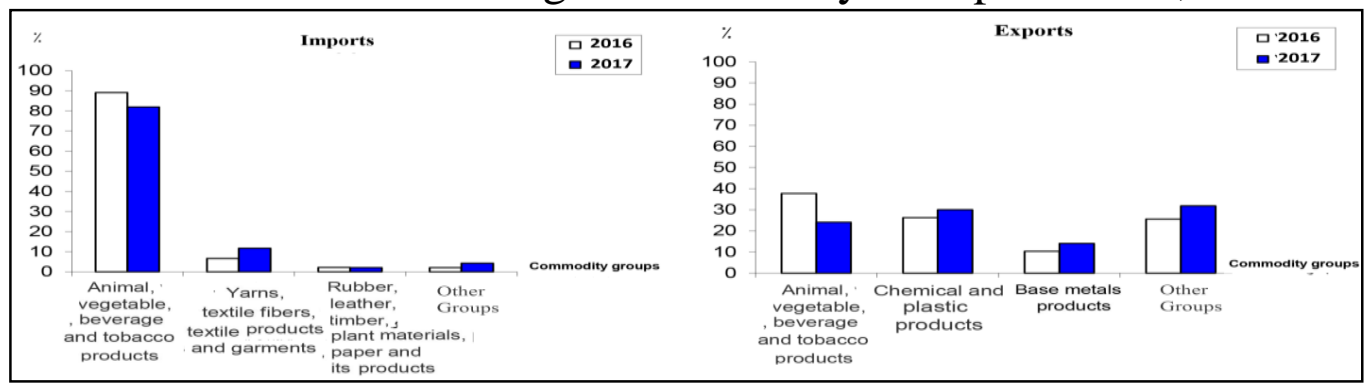

Source: CAPMAS, 2018.

Figure (3) shows the relative distribution of Egypt's exports and imports to the Nile Basin Countries according to commodity groups, so animal, vegetable, beverage, and tobacco products represent $80 \%$ of Egypt's imports from the Nile Basin countries in 2017. Chemicals plastic products represent 30\% of Egypt's exports to the Nile Basin countries then animal, vegetable, beverage, and tobacco products represent $20 \%$, and base metals products $10 \%$ in 2017.

The following figures show the distribution of the most important exports and imports of Egypt to each country of the Nile Basin countries.

Figure (4) Relative Distribution of Egypt's most Important Exports to

Sudan According to Items in 2016, 2017

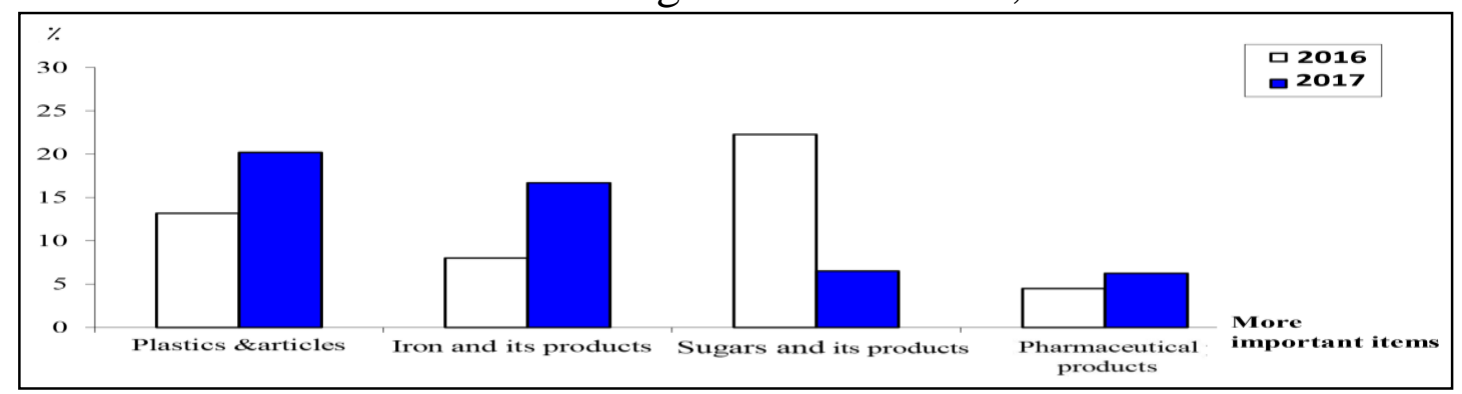

Source: CAPMAS, 2018.

Figure (4) shows the relative distribution of Egypt's most important exports to Sudan, that plastic and articles represent 20\%, then iron and its products $15 \%$, sugar, and its products $5 \%$, and pharmaceutical products $5 \%$ of Egypt's exports to Sudan at 2017.

Figure (5) Relative Distribution of Egypt's most Important Imports from

Sudan According to Items in 2016, 2017

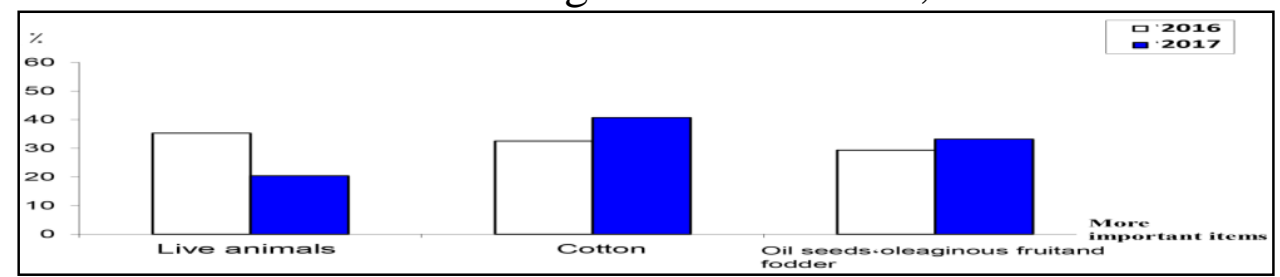

Source: CAPMAS, 2018. 
Figure (5) shows the relative distribution of Egypt's most important imports from Sudan, that cotton represents $40 \%$, then oil seeds $30 \%$, and live animals 20\% of Egypt's imports from Sudan at 2017.

Figure (6) Relative Distribution of Egypt's most Important Exports to Ethiopia According to Items in 2016, 2017

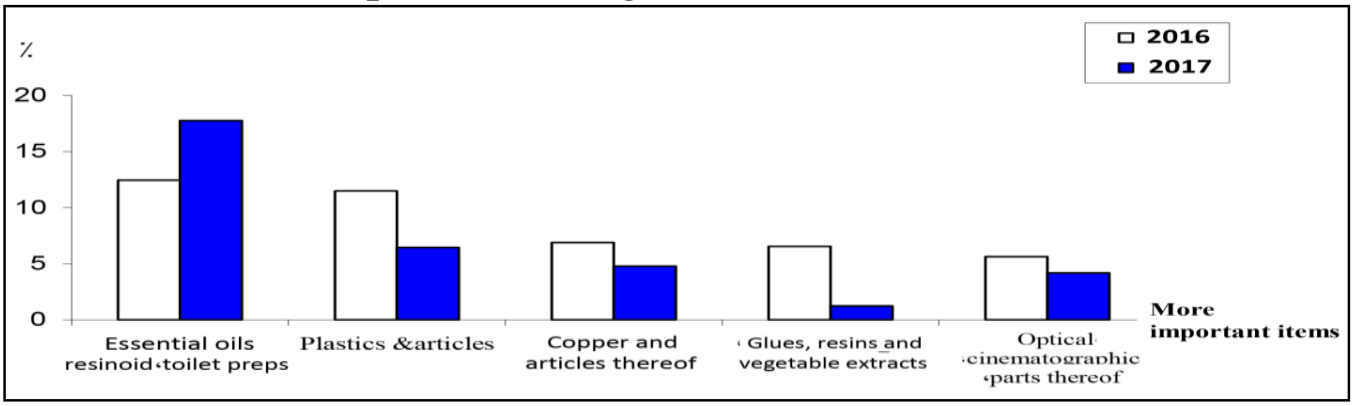

Source: CAPMAS, 2018.

Figure (6) shows the relative distribution of Egypt's most important exports to Ethiopia that essential oils preps represent $18 \%$, then plastic and articles 7\%, copper 5\%, optical cinematographic parts 5\%, and glues \& vegetables extract 2\% of Egypt's exports to Ethiopia at 2017.

Figure (7) Relative Distribution of Egypt's most Important Imports from Ethiopia According to Items in 2016, 2017

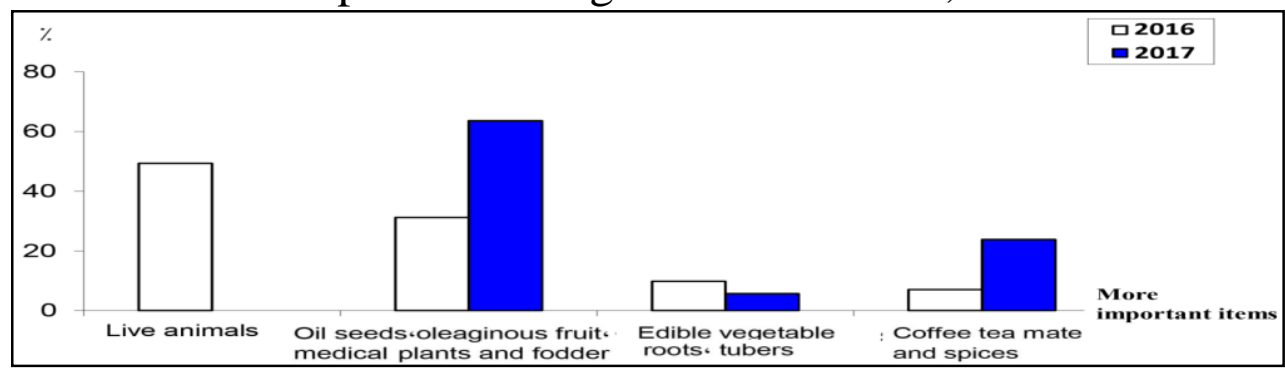

Source: CAPMAS, 2018.

Figure (7) shows the relative distribution of Egypt's most important imports from Ethiopia that oil seeds represent $60 \%$, then coffee, tea mate, and spices $20 \%$ and vegetable roots 2\%, of Egypt's imports from Ethiopia at 2017.

Figure (8) Relative Distribution of Egypt's most Important Exports to Uganda According to Items in 2016, 2017

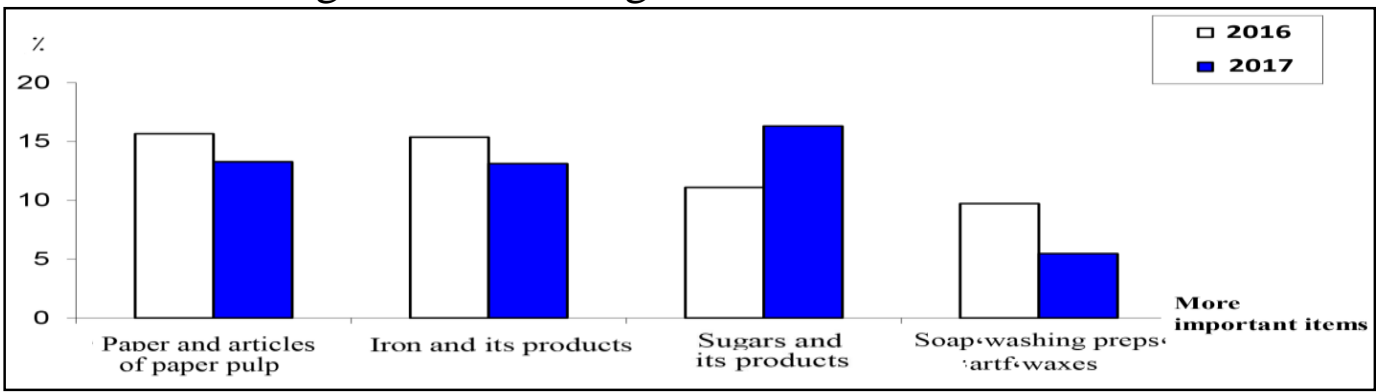

Source: CAPMAS, 2018. 
Figure (8) shows the relative distribution of Egypt's most important exports to Uganda that paper and articles of paper pulp represent about 15\%, iron and its product $15 \%$, sugar, and its product $17 \%$, and soap washing preps $5 \%$, of Egypt's exports to Uganda at 2017.

Figure (9) Relative Distribution of Egypt's most Important Imports from Uganda According to Items in 2016, 2017

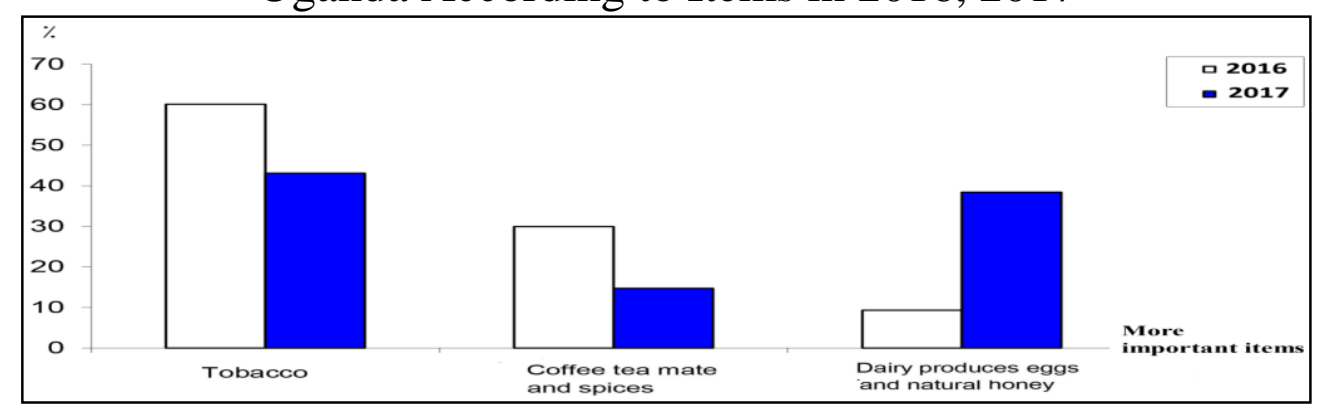

Source: CAPMAS, 2018.

Figure (9) shows the relative distribution of Egypt's most important imports from Uganda that tobacco represents 40\%, dairy produces eggs $35 \%$ then coffee, tea mate, and spices $15 \%$ of Egypt's imports from Uganda in 2017.

Figure (10) Relative Distribution of Egypt's most Important Exports to Congo According to Items in 2016, 2017

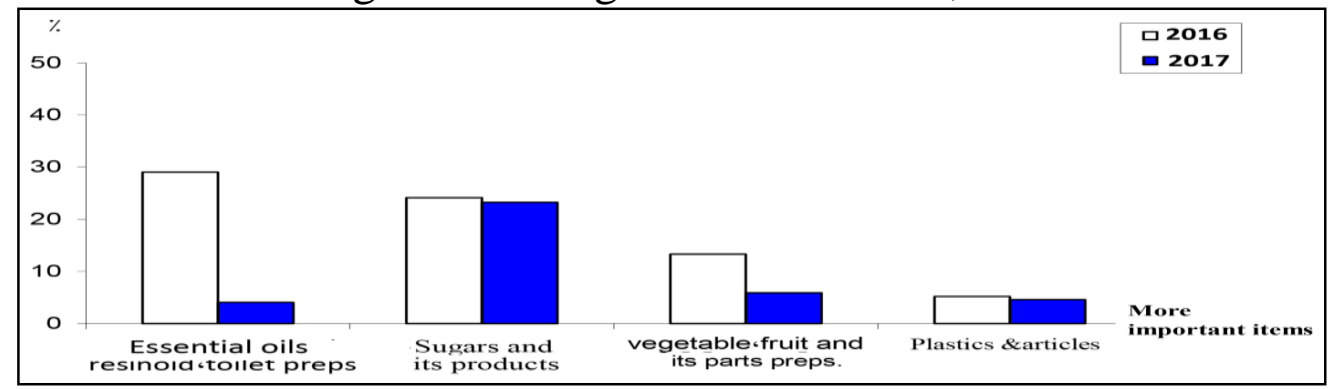

Source: CAPMAS, 2018.

Figure (10) shows the relative distribution of Egypt's most important exports to Congo that sugar and its product represent $25 \%$, vegetables, fruits, and its parts preps $7 \%$, essential oils preps $5 \%$ and plastic \& articles $5 \%$ of Egypt's exports to Congo at 2017.

Figure (11) Relative Distribution of Egypt's most Important Imports from Congo According to Items in 2016, 2017

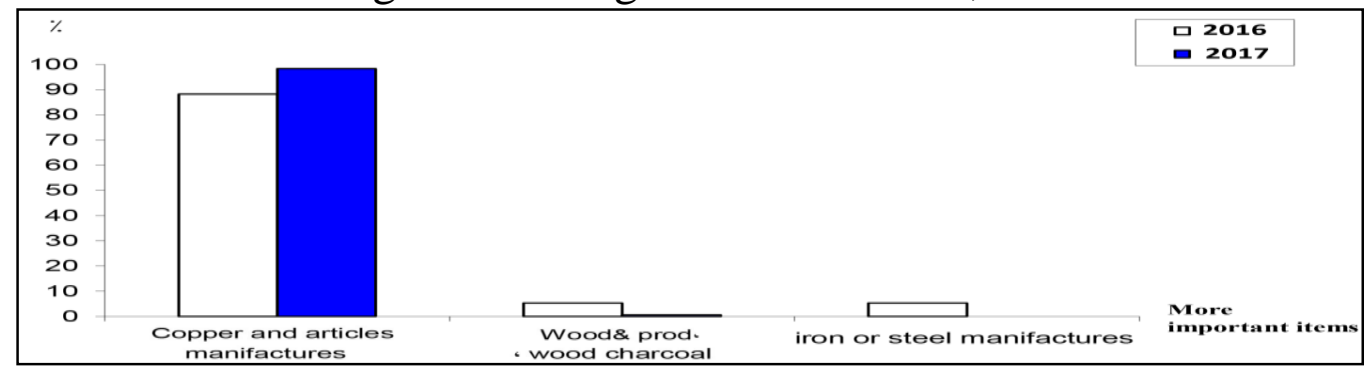

Source: CAPMAS, 2018. 
Figure (11) shows the relative distribution of Egypt's most important imports from Congo that copper and articles manufacture represent about 99\%, and wood \& its product 1\% of Egypt's imports from Congo in 2017.

Figure (12) Relative Distribution of Egypt's most Important Exports to Kenya According to Items in 2016, 2017

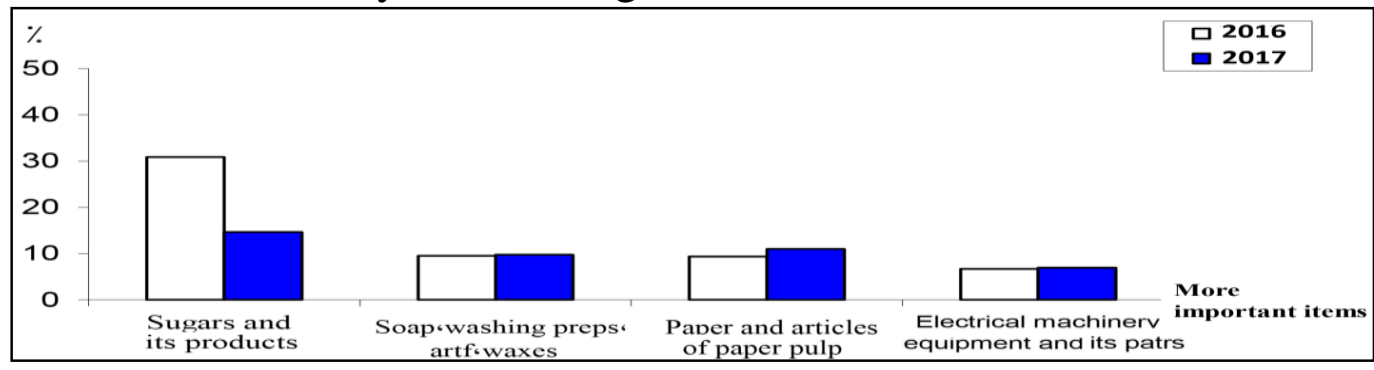

Source: CAPMAS, 2018.

Figure (12) shows the relative distribution of Egypt's most important exports to Kenya that sugar and its product represent $15 \%$, soap washing preps $10 \%$, paper, and articles of paper pulp 10\%, and electrical machinery equipment \& its parts 5\% of Egypt's exports to Kenya at 2017.

Figure (13) Relative Distribution of Egypt's most Important Imports from Kenya According to Items in 2016, 2017

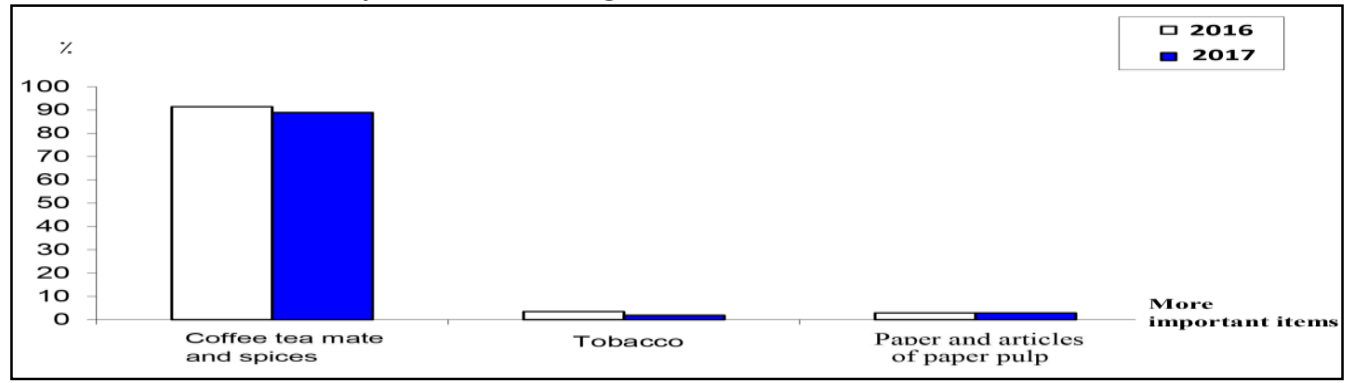

Source: CAPMAS, 2018.

Figure (13) shows the relative distribution of Egypt's most important imports from Kenya that coffee, tea mate, and spices represent about $90 \%$, tobacco $2 \%$, and paper \& articles of paper pulp 2\% of Egypt's imports from Kenya at 2017.

Figure (14) Relative Distribution of Egypt's most Important Exports to Tanzania According to Items in 2016, 2017

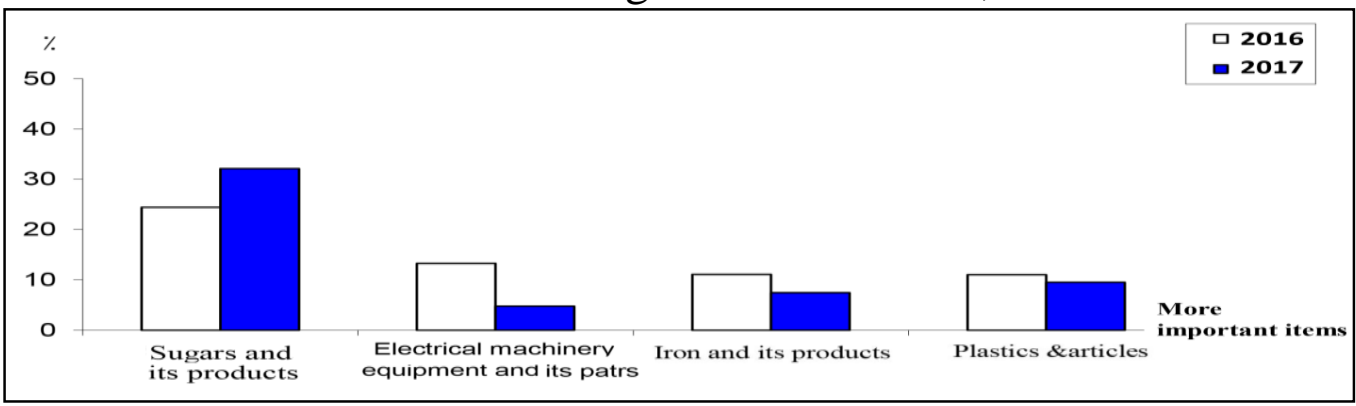

Source: CAPMAS, 2018. 
Figure (14) shows the relative distribution of Egypt's most important exports to Tanzania that sugar and its product represent $32 \%$, plastic \& articles $10 \%$, iron \& its products $8 \%$, and electrical machinery equipment $\&$ its parts 5\% of Egypt's exports to Tanzania at 2017.

Figure (15) Relative Distribution of Egypt's most Important Imports from Tanzania According to Items in 2016, 2017

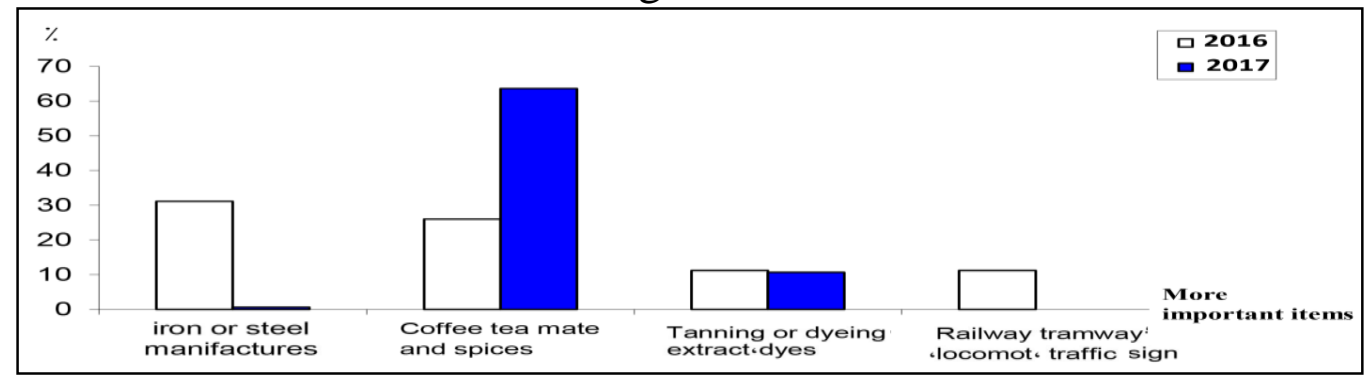

Source: CAPMAS, 2018.

Figure (15) shows the relative distribution of Egypt's most important imports from Tanzania that coffee, tea mate, and spices represent about 60\%, tanning or dyeing extract dyes $10 \%$ and iron or steel manufactures $1 \%$ of Egypt's imports from Tanzania at 2017.

Figure (16) Relative Distribution of Egypt's most Important Exports to Rwanda According to Items in 2016, 2017

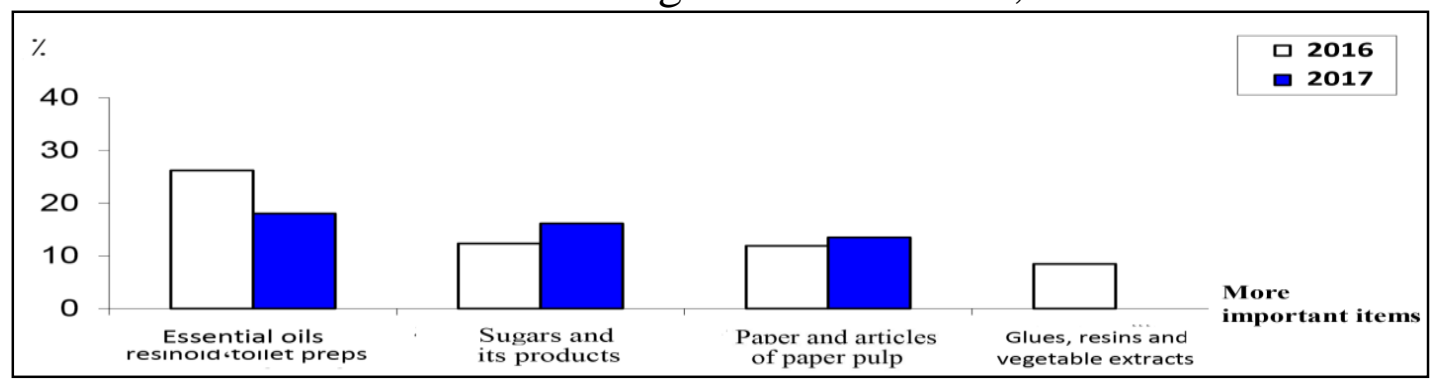

Source: CAPMAS, 2018.

Figure (16) shows the relative distribution of Egypt's most important exports to Rwanda that sugar and its product represent $15 \%$, plastic \& articles $10 \%$, iron $\&$ its products $8 \%$, and electrical machinery equipment $\&$ its parts 5\% of Egypt's exports to Rwanda at 2017.

Figure (17) Relative Distribution of Egypt's most Important Exports to Burundi according to items in 2016, 2017

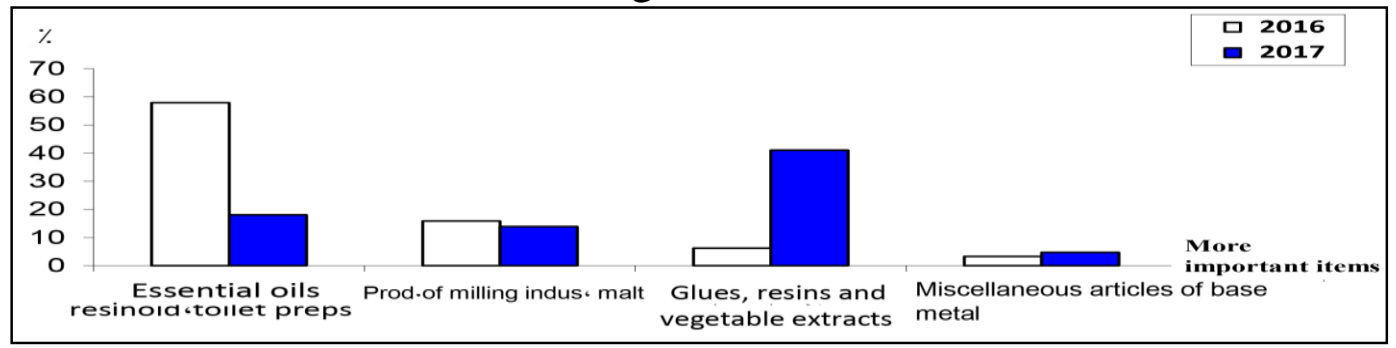

Source: CAPMAS, 2018. 
Figure (17) shows the relative distribution of Egypt's most important exports to Burundi that glues, resins and vegetables extract $40 \%$, essential oil preps $18 \%$, product of milling industry malt $15 \%$, and miscellaneous articles of base metal 5\% of Egypt's exports to Burundi at 2017.

Figure (18) Relative Distribution of Egypt's most Important Exports to Eretria According to Items in 2016, 2017

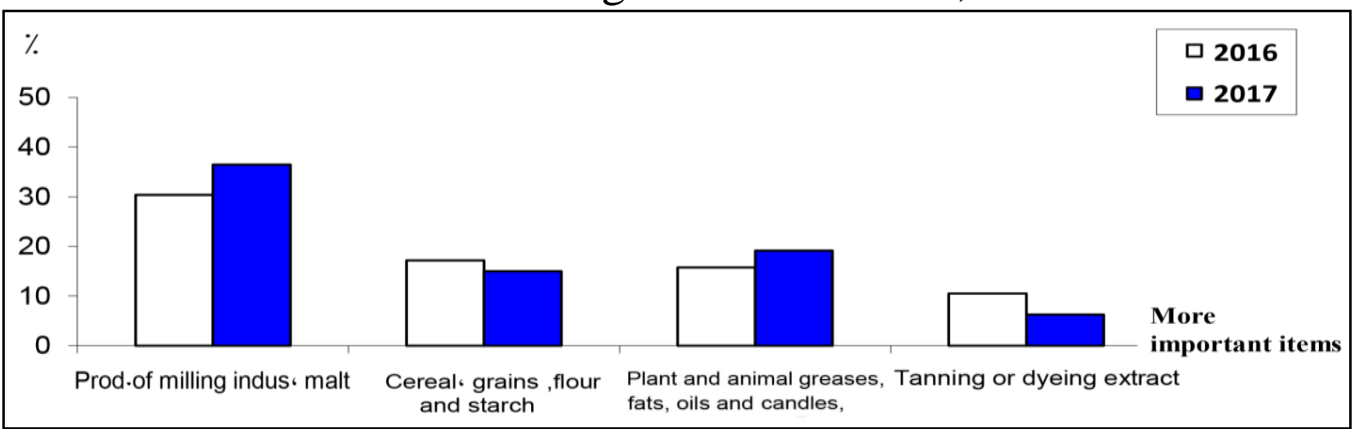

Source: CAPMAS, 2018.

Figure (18) shows the relative distribution of Egypt's most important exports to Eretria that product of milling industry malt $35 \%$, plant \& animal greases, fats, oils, and candles $20 \%$, cereal, grains, flour and starch $18 \%$ and tanning or dyeing extract about 5\% of Egypt's exports to Eretria at 2017.

\section{Third: the Economic Indicators on Trade between Egypt and the Nile Basin Countries}

(1) The Trade Intensity Index

The formula used by (Hanink \& Owusu, 1998) defined the index as a measure of intra-trade flows between countries so that if the index takes a value greater than (1) it indicates the rate is (acceptable) for trade flows Between the two parties, and if the index takes a value less than (1), it indicates the rate is (unacceptable) and not good for trade flows. ${ }^{9}$

TIInm $=(\mathrm{Xnm} / \mathrm{Xnw}) /(\mathrm{Xwm} / \mathrm{Xww})$

Xnm exports by country $n$ to country m (Egypt's exports to Nile Basin countries)

Xnw total exports of the country $n$ to the world (Egypt's exports to the World)

Xwm World exports to the country m (imports of Nile Basin countries from the World) Xww total exports of the World 
Figure (19) Trade Intensity Index between Egypt and the Nile Basin during the Period (2000-2017)

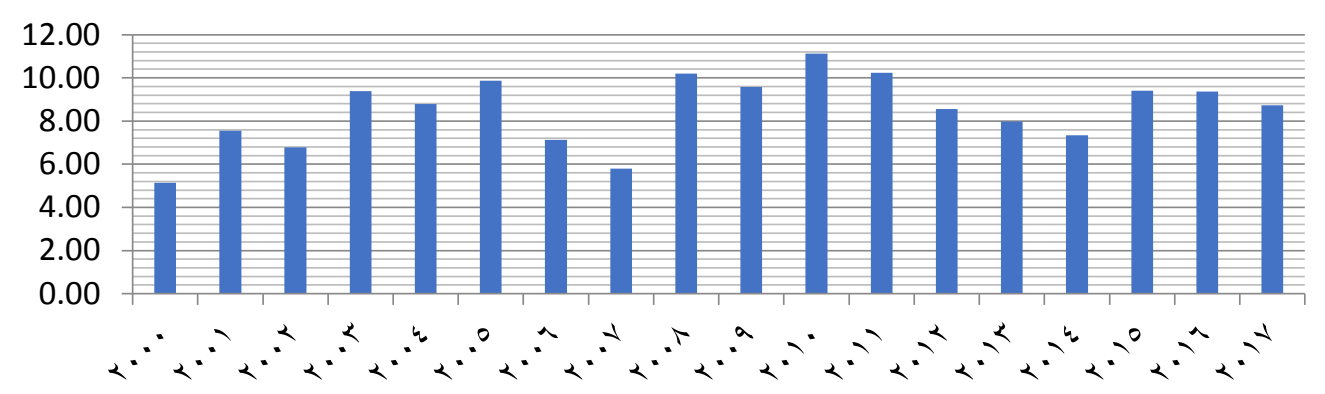

Source: by the author using data of Central Agency for Public Mobilization and Statistics Database, CAPMAS https://www.capmas.gov.eg, Statistics of UNCTAD Website http://unctadstat.unctad.org/EN, World Bank Database www.worldbank.org

Figure (19) shows that the index of trade intensity between Egypt and the Nile Basin countries was greater than (1) during the period (2000-2017) so the rate was (acceptable) for the Nile Basin countries as a group.

Table (1) Trade Intensity Index between Egypt and Countries of the Nile Basin during the Period (2000-2017)

\begin{tabular}{|c|c|c|c|c|c|c|c|c|c|}
\hline & Kenya & Ethiopia & Uganda & Congo & Tanzania & Burundi & Rwanda & Eretria & Sudan \\
\hline 2000 & 5.2 & 2.1 & 1.6 & 0.4 & 1.3 & 1.2 & 4.8 &.. & 27.8 \\
\hline 2001 & 11.5 & 2.5 & 0.8 & 3.2 & 4.1 & 1.3 & 0.4 & 2 & 26.9 \\
\hline 2002 & 7.7 & 4.4 & 0.9 & 0.3 & 1.3 & 1.3 & 0.7 & 4 & 24.8 \\
\hline 2003 & 9.3 & 2.7 & 1.5 & 0.2 & 2.4 & 1 & 3.5 & 3.8 & 42.5 \\
\hline 2004 & 10.5 & 2.2 & 1.1 & 0.1 & 2 & 0.4 & 3.1 & 3.1 & 36 \\
\hline 2005 & 9.8 & 5.6 & 1.1 & 0.2 & 2.7 & 0.9 & 1.4 & 4.8 & 33 \\
\hline 2006 & 6.7 & 2 & 1.6 & 0.6 & 1.8 & 0.3 & 0.4 & 1.3 & 26 \\
\hline 2007 & 9.1 & 1.4 & 1.6 & 0.6 & 1.4 & 0.3 & 0.4 & 1.4 & 20.1 \\
\hline 2008 & 7.8 & 5.9 & 2 & 1.2 & 2.2 & 6.1 & 5.1 & 12.6 & 43.2 \\
\hline 2009 & 7.4 & 3.5 & 3.2 & 3.6 & 1.8 & 21 & 6.1 & 23.5 & 37.8 \\
\hline 2010 & 13.9 & 3.8 & 2.9 & 3.2 & 2.5 & 22.1 & 7.3 & 32.2 & 39.8 \\
\hline 2011 & 11 & 3.8 & 2.9 & 2.2 & $\mathbf{3}$ & 13.2 & 6.6 & 31.2 & 41.2 \\
\hline 2012 & 13.4 & 3.5 & 3.7 & 3.1 & 3.6 & 11.7 & 6.5 & 26.4 & 37,9 \\
\hline 2013 & 10.8 & 4.3 & 9.5 & 1,8 & 2,0 & 10,5 & 6,4 & 50.2 & 43,8 \\
\hline 2014 & 10.7 & 4.9 & 6.1 & 1,7 & 2,5 & 8,7 & 7,9 & 40.7 & 37,2 \\
\hline 2015 & 12,6 & 2.4 & 4.7 & 1,3 & 3,8 & 26.4 & 5,0 & 59.4 & 48,7 \\
\hline 2016 & 16,2 & 2.6 & 5.6 & 1,9 & 4,5 & 21,4 & 5,6 & 50.8 & 34,9 \\
\hline$\overline{2017}$ & 10,6 & 3.1 & 5.5 & 1,7 & 2,8 &.. & $\overline{5,0}$ &.. & 32,1 \\
\hline
\end{tabular}

Source: by the author using data of CAPMAS, Statistics of UNCTAD, and the World Bank Database. 
Figure (20) Trade Intensity Index between Egypt and Countries of the Nile Basin during the period (2000-2017)

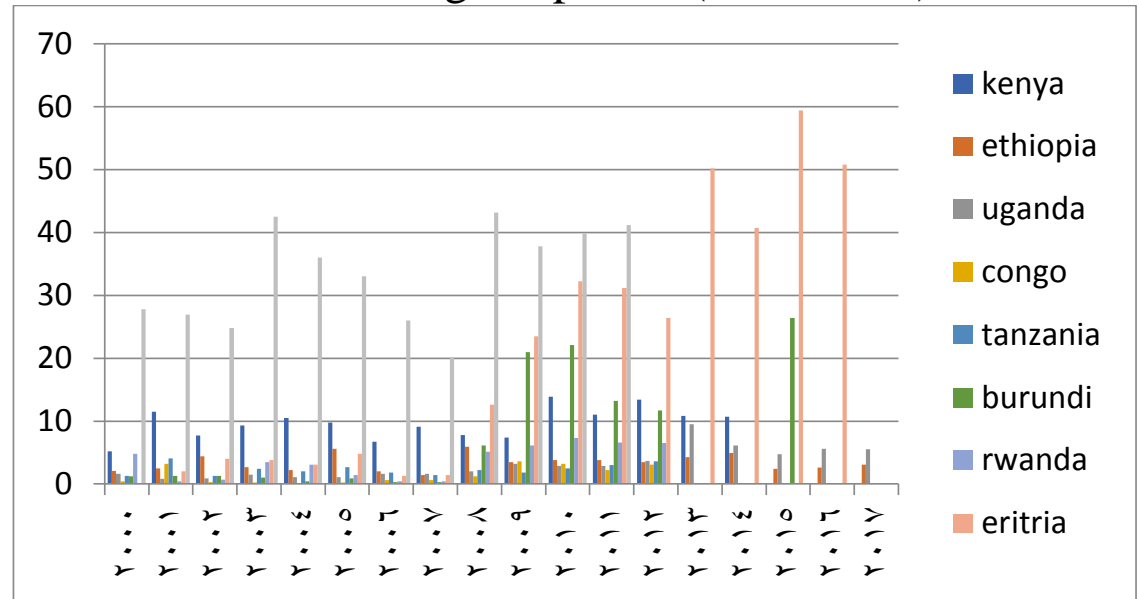

Source: by the author using data of CAPMAS, Statistics of UNCTAD, and the World Bank Database.

The previous table and figure show that the index of trade intensity between Egypt and the Nile Basin countries was greater than (1) in all the Nile Basin countries for most period of the study, and so the rate was (acceptable) and but (more acceptable) In Sudan, Kenya, Burundi, Rwanda, and Eritrea.

2- The Absorptive Capacity Index in the Nile Basin Countries for Egypt's Exports

The index is used to measure the ability of a country's market to absorb the imports of another country, and the values range to (zero, 100). Whenever the values are closer to (100), it indicates the strength and ability of the country to absorb another country's exports and vice versa. ${ }^{10}$

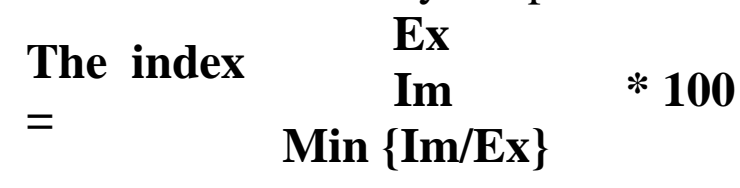


Figure (21) The Absorptive Capacity Index in the Nile Basin Countries for Egypt's Exports during the Period (2000-2016)

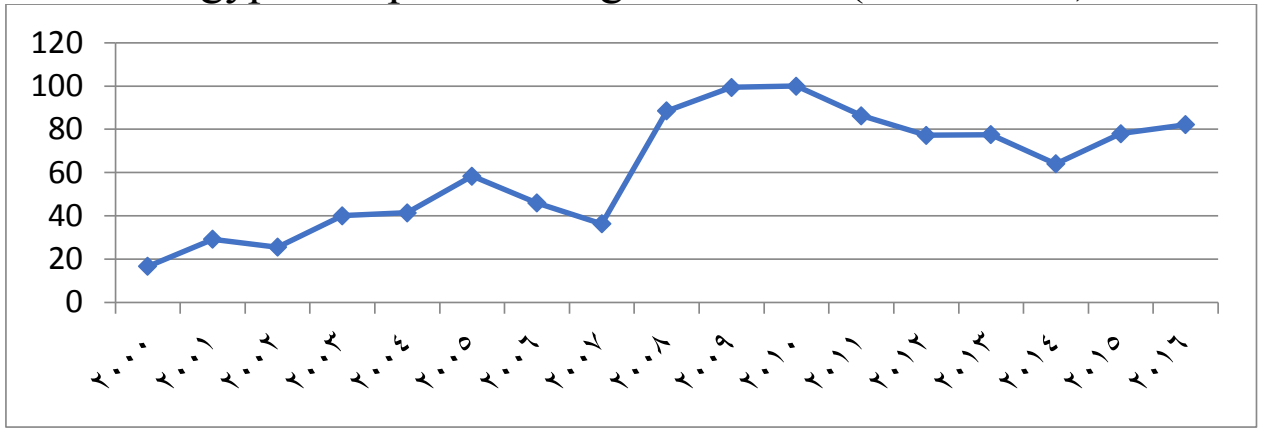

Source: by the author using data of CAPMAS, Statistics of UNCTAD, and the World Bank Database.

Figure (21) shows that the index limited to the values (12 - 100), and the index was closer to (100) in years $(2014,2015,2016)$, where the index was $(64,78,82)$ respectively, and equal to 100 in 2009 and 2010, so the opportunities of the Nile Basin countries to absorb Egyptian exports is considered good and strong.

3- The Exports Similarity Index between Egypt and the Nile Basin Countries

The index measures the similarity of exports between Egypt on one side and the Nile Basin countries on the other hand

Exports Similarity $=\left[\sum \operatorname{Min}\left\{\mathbf{X}_{\mathbf{i}}(\mathbf{a c}), \mathbf{X}_{\mathbf{i}}(\mathbf{b c})\right\} * 100\right]$

$X_{i}(a c)$ : the percentage of sector $c$ exports of the total exports of country a

$X_{i}(b c)$ : the percentage of sector c exports of the total exports of country b

The index value ranges between (zero - hundred), so the higher value of indicator indicates an increase of similarity between the commodity export structure between the two countries and thus the possibility of creating trade between them and vice versa. ${ }^{11}$

Figure (22) Exports Similarity Index between Egypt and the Nile Basin Countries in 2017

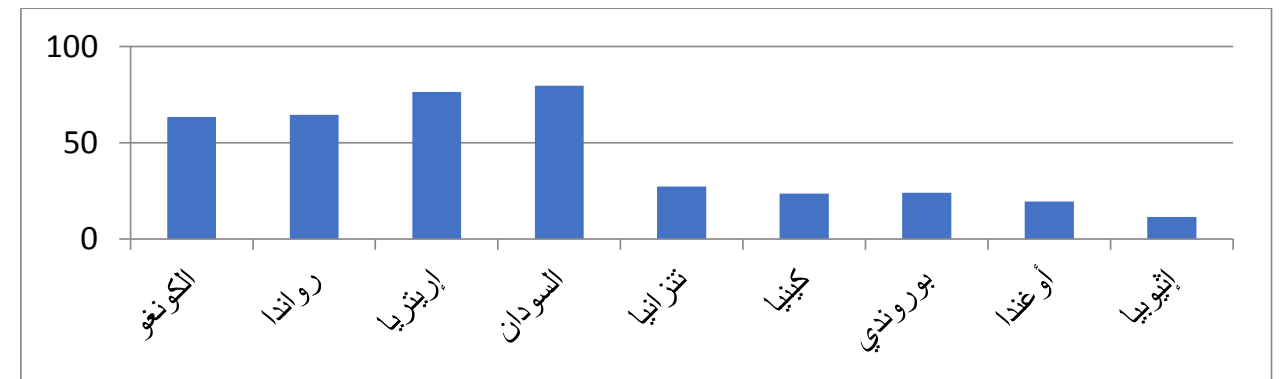

Source: by the author using data of CAPMAS, Statistics of UNCTAD, and the World Bank Database. 
Figure (22) shows high values of the index in (Eritrea, Rwanda, Congo, and Sudan), that equal $(76,64,63,79)$ respectively, this indicates the similarity between the productive structures of Egypt and these countries, so the production structures are more competitive and not integrated, and therefore the potential for creating trade between Egypt and these countries is weak. While values of the index in (Tanzania, Burundi, Uganda, Ethiopia, and Kenya) equal $(27,23,19,11,23)$ respectively, This indicates low similarity between the productive structures of Egypt and these countries, so the production structures are more integrated and there is a possibility for creating trade between Egypt and these countries.

4- The Coverage Ratio of Egypt's Exports to the Nile Basin Countries' Imports

The ratio is calculated by the following formula:-

Egypt's Exports in year $n$

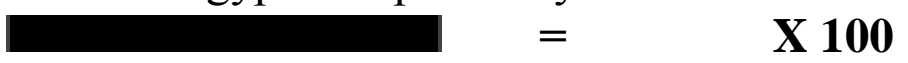

Nile Basin Countries' Imports in year n

Figure (23) The Coverage Ratio of Egypt's Exports to the Nile Basin Countries' Imports during the Period (2000-2018)

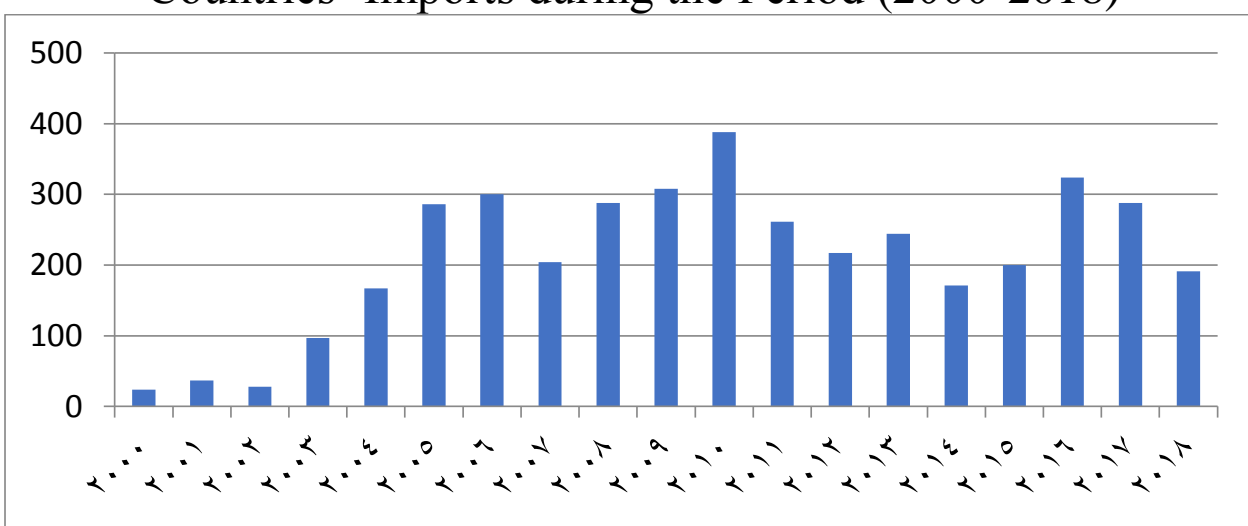

Source: by the author using data of CAPMAS, Statistics of UNCTAD, and the World Bank Database.

Figure (23) shows the coverage ratio in 2018 was (191\%), so that Egypt's Exports coverage the Nile Basin Countries' Imports. Nevertheless, Egypt should increase its relations with the Nile basin countries by increasing Egypt's exports. 


\section{Fourth: Measuring Determinants of Trade Intensity between Egypt and the Nile Basin Countries}

The study of Fortune and Pritchett is one of the reference studies that measured the intensity of trade and identified its determinants, in addition to the study of (Hanink \& Owusu, 1998), which presented analysis tools for measuring the intensity of trade and their determinants. ${ }^{12}$

The authors focused on the method of measuring trade intensity using the gravity model after describing it with real variables. According to the model presented by Hanink and Owusu, the following model can be presented for the determinants of trade intensity between Egypt and the Nile basin countries during the period (2000-2018):

$\mathrm{TRT}=\mathrm{f}\left(\mathrm{GDP}_{\mathrm{E}}, \mathrm{GDP}_{\mathrm{N}}, \mathrm{GDP}_{\mathrm{E}}\right.$ per capita, $\mathrm{GDP}_{\mathrm{N}}$ per capita, $\left.\mathrm{TWT}\right)$

TRF trade intensity index between Egypt and the Nile Basin countries $\mathrm{GDP}_{\mathrm{E}}$ the gross domestic product of Egypt

$\mathrm{GDP}_{\mathrm{N}}$ the gross domestic product of the Nile Basin countries

$\mathrm{GDPPC}_{\mathrm{E}}$ the GDP per capita of Egypt

GDPPC $_{N}$ the GDP per capita of the Nile Basin countries

TWT Egypt's trade to the Nile Basin countries

The study relies on the World Bank database which provides data on the gross domestic product of Egypt and the Nile Basin countries, in addition to the GDP per capita of Egypt and the Nile basin countries. And the study relies on reports issued by the Central Agency for Public Mobilization and Statistics in Egypt which provides data on Egypt's trade to the Nile Basin countries. The variable TRT trade intensity index between Egypt and the Nile Basin countries is calculated by the author and is presented in table 1.

The Unit Root Test is performed through the Augmented Dicky Fuller ADF test to examine the stability of time series. The null hypothesis is: the time series has a unit root problem (the time series is not static), the Alternative Hypothesis: The time series does not have a root unit problem (the time series is static).

Table 2 shows the results of the unit root test, after comparing the calculated value with the tabular value, the calculated value is greater than the tabular value at the level for $\left(\mathrm{GDP}_{\mathrm{E}}, \mathrm{GDP}_{\mathrm{N}}, \mathrm{GDPPC}_{\mathrm{E}}, \mathrm{GDPPC}_{\mathrm{N}}\right.$ and TWT), so these time series are not static, and by taking first Difference, the calculated value be less than the tabular value for $\left(\mathrm{GDP}_{\mathrm{E}}\right.$ and $\left.\mathrm{GDPPC}_{\mathrm{N}}\right)$, so the time series of the first differences are static with a confidence degree of 99\%, and by taking second Difference, the calculated value be less than the tabular value for $\left(\mathrm{GDP}_{\mathrm{N}}, \mathrm{GDPPC}_{\mathrm{E}}\right.$ and TWT), so the time series of the second differences are static with a confidence degree of $99 \%$, and the test results show that the time series of TRT is static at the level with a confidence degree of $95 \%$. 
Variables

\author{
Calculated value
}

Level
Table (2) The Unit Root Test Results
Tabular value

$$
\% 5 \quad \% 10
$$

Difference difference

\begin{tabular}{|c|c|c|c|c|c|c|}
\hline TRT & $\begin{array}{c}- \\
3.551379\end{array}$ & & & -3.886751 & -3.052169 & -2.666593 \\
\hline $\mathrm{GDP}_{\mathrm{E}}$ & & -4.131621 & & -4.057910 & -3.119910 & -2.701103 \\
\hline $\mathrm{GDP}_{\mathrm{N}}$ & & & -4.368619 & -3.959148 & -3.081002 & -2.681330 \\
\hline $\mathrm{GDPPC}_{\mathrm{E}}$ & & & $\begin{array}{l}- \\
2.876133\end{array}$ & -2.771926 & -1.974028 & -1.602922 \\
\hline $\mathrm{GDPPC}_{\mathrm{N}}$ & & -4.534271 & & -3.959148 & -3.081002 & -2.681330 \\
\hline TWT & & & $\begin{array}{l}- \\
5.565936\end{array}$ & -3.959148 & -3.081002 & -2.681330 \\
\hline
\end{tabular}

Source: Author using Eviews 8.

After estimating the parameters, the estimated equation is as follow: $\mathrm{TRT}=34.0454+1.29475 * \mathrm{GDPE}+0.55029 * \mathrm{GDPN}+0.63978 * \mathrm{GDPPCE}$ $+0.22831 * \mathrm{GDPPCN}+$

\section{$2.51367 * \mathrm{TWT}$}

Table 3 displays the estimated results.

\begin{tabular}{|c|c|c|c|c|}
\hline \multirow[b]{2}{*}{ Variables } & \multicolumn{3}{|c|}{ Table (3) Results of the Model } & \multirow[b]{2}{*}{ Prob. } \\
\hline & Coefficient & Std. Error & t-Statistic & \\
\hline Constant & 34.0454 & 14.61007 & 2.330274 & 0.0381 \\
\hline $\mathrm{GDP}_{\mathrm{E}}$ & 1.29475 & 0.419760 & 3.084519 & 0.0095 \\
\hline $\mathrm{GDP}_{\mathrm{N}}$ & 0.55029 & 0.179122 & -3.072168 & 0.0097 \\
\hline $\mathrm{GDPPC}_{\mathrm{E}}$ & 0.63978 & 0.024178 & -2.646117 & 0.0213 \\
\hline $\mathrm{GDPPC}_{\mathrm{N}}$ & 0.22831 & 0.003797 & -0.601136 & 0.0558 \\
\hline TWT & 2.51367 & 1.464704 & -1.716168 & 0.0111 \\
\hline R-squared & 0.9642 & F-statistic & 2.779329 & 2.031355 \\
\hline & & rob (F-stat & 0.0681 & \\
\hline
\end{tabular}

Source: Author using Eviews 8. 
Table (4) Results of Correlation between variables

\begin{tabular}{||ccccccc||}
\hline & TRT & GDPE & GDPN & GDPPCE & GDPPCN & TWT \\
\hline \hline TRT & 1.000000 & 0.396791 & 0.344071 & 0.448676 & 0.375496 & 0.407117 \\
GDPE & 0.396791 & 1.000000 & 0.992677 & 0.982989 & 0.995528 & 0.917611 \\
GDPN & 0.344071 & 0.992677 & 1.000000 & 0.954252 & 0.989426 & 0.892407 \\
GDPPCE & 0.448676 & 0.982989 & 0.954252 & 1.000000 & 0.977166 & 0.920274 \\
GDPPCN & 0.375496 & 0.995528 & 0.989426 & 0.977166 & 1.000000 & 0.914678 \\
TWT & 0.407117 & 0.917611 & 0.892407 & 0.920274 & 0.914678 & 1.000000 \\
\hline
\end{tabular}

Source: Author using Eviews 8.

- The explanatory level of the model: R-squared is equal to 0.9642 which mean that the independent variables can explain about $96.4 \%$ of the changes in the variable of trade intensity index between Egypt and the Nile Basin countries, and the rest is due to other factors, including random errors.

- The overall significance of the model: the results show that the value of (F-statistic) equal to 2.78 and it is statistically significant, which means rejecting the null hypothesis that the estimated regression model is not significant, and accepting the alternative hypothesis so the estimated model is significant, this indicates the independent variables have a significant effect on the dependent variable.

- The partial significance of the model: It is noted from the results that the parameters are statistically significant, which indicates that these parameters differ substantially from zero, which reflects the importance of these independent variables.

- Standard parameters of the model: the value of the Durbin Watson coefficient in this model is 2.03 and by examining the corresponding tabular value, the Durbin Watson indicates that there is no false slope, and the estimated model is free of the problem of linear correlation between the independent variables.

- Economic interpretations of the estimated parameters: the estimated results are consistent with the economic theory. 
Figure (24) Forecasting of the model

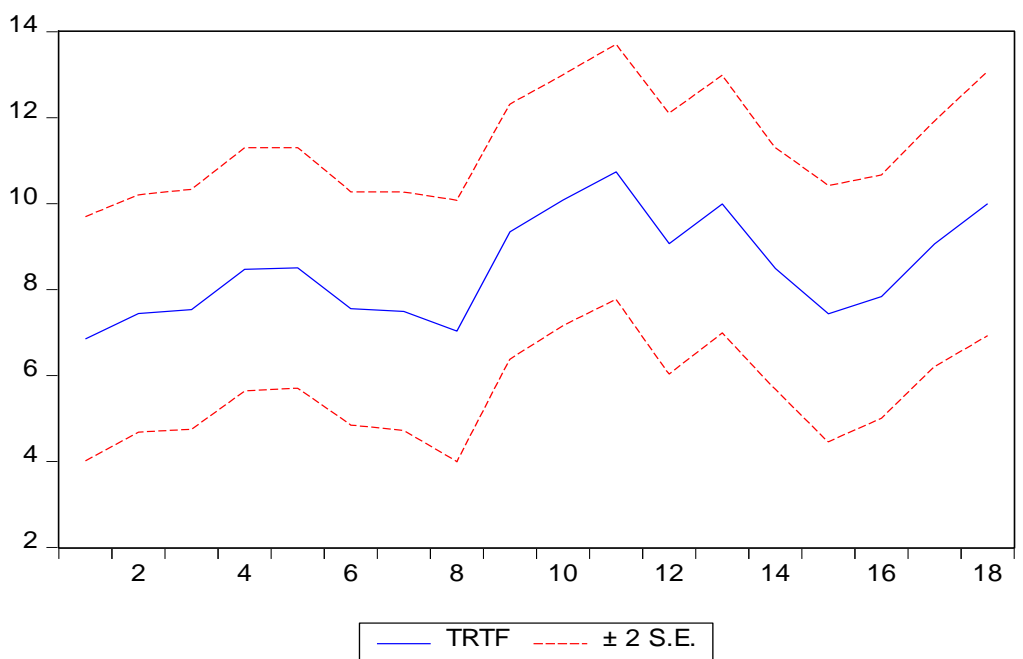
Forecast: TRTF
Actual: TRT
Forecast sample: 118
Included observations: 18
Root Mean Squared Error
Mean Absolute Error
1.067425
Mean Abs. Percent Error
0.878185
Theil Inequality Coefficient
Bias Proportion
10.91597
0.062025
Variance Proportion
Covariance Proportion
Theil U2 Coefficient
0.000000
0.154372
0.845628
Symmetric MAPE
0.454872
10.70656

Source: Author using Eviews 8.

The results indicate that there is a positive relationship between $\mathrm{GDP}_{\mathrm{E}}$ and $\mathrm{GDP}_{\mathrm{N}}$ with the trade intensity index between Egypt and the Nile Basin countries, as a change in $\mathrm{GDP}_{\mathrm{E}}$ and $\mathrm{GDP}_{\mathrm{N}}$ by one unit lead to an increase in the trade intensity index by 1.29 and 0.55 units respectively. The GDP per capita of Egypt and the Nile Basin countries affect positively the trade intensity index, a change in $\mathrm{GDPPC}_{\mathrm{E}}$ and $\mathrm{GDPPC}_{\mathrm{N}}$ by one unit leads to an increase in the trade intensity index by 0.64 and 0.23 units respectively.

The effect of Egypt's trade to the Nile Basin countries on the trade intensity index is positive and significant, so increase Egypt's trade to the Nile Basin countries by one unit leads to an increase in the trade intensity index by 2.51 units. This may reflect the importance of this variable TWT on the trade intensity index between Egypt and the Nile Basin countries.

Fifth: SWOT Analysis (Strengths, Weaknesses, Opportunities, and Threats)

It is an analysis tool that determines the aspects of Strengths, Weaknesses, Opportunities, and Threats, so the SWOT analysis for the trade relation between Egypt and the Nile Basin countries as follows:-

\section{A- Strengths}

1- Strengths of the Egyptian economy

(1) Egypt's strategic geographical location, Egypt is considered one of the most important international trade corridors between East and West, there are several naval channels and roads, such as the Nile River.

(2) The human resources, Egypt is one of the most populated countries in the Middle East, and is a young country, with a population of fewer 
than 30 years of age represent $61 \%$ of the total population, in addition to the large size of the consumer market. Egypt also has a network of international trade agreements that enable it to be a center of trade in the Middle East. ${ }^{13}$

(3) Diversification of the Egyptian economy, which depends mainly on the services sector, the revenues of the oil sector, agricultural production and manufacturing industries, and the revenues of tourism and the income of the Suez Canal, which makes the Egyptian economy diversified, It gives Egypt a greater opportunity to participate and integrate into the production and value chains at the global level.

(4) The availability of many real and sustainable investment opportunities represent a tangible positive impact on achieving development in Egypt.

(5) The Energy resource, Egypt is one of the most promising countries in the fields of renewable energy production. Egypt also has many minerals as "energy ores, solid energy ores, radioactive ores, metallic ores, and ferrous ores". ${ }^{14}$

\section{2- Strengths of the Nile Basin countries}

(1) Human resources, the population of Nile Basin countries amount to 502.4 million people in 2017, with a total area of 8.9 million $\mathrm{km}^{2}{ }^{2}{ }^{5}$

(2) Mineral resources and energy, the Nile Basin countries possess stocks of many strategic wealth and minerals, such as gold in eastern Sudan, copper in Sudan and Congo, petroleum in Egypt and Sudan, as well as diamonds in Congo. ${ }^{16}$

(3) Agricultural resources, the Nile Basin countries are characterized by the diversity of their climatic regions, with different levels and types of rich soil, and various agricultural seasons, which makes the Nile Basin an "appropriate environment for the cultivation and production of all crops, grains, and vegetables", so investment in the agricultural field is one of the best options to achieve the economic growth and food security.

(4) The availability of water resources represented by the Nile River, which is $6695 \mathrm{~km}$, in addition to the high rates of rainfall in some of the Nile Basin regions, and the huge reservoir of groundwater. ${ }^{17}$

\section{B- Weaknesses}

The main obstacles facing the trade relation between Egypt and the Nile Basin countries are as follows: 
1- Obstacles related to Egypt

(1) The weak presence of Egyptian goods in exhibitions held in the Nile Basin countries, in addition to the limitations of advertising on Egyptian goods.

(2) Canceling the flights of Egypt Air to a number of Nile Basin countries, such as Tanzania.

(3) The absence of Egyptian companies to secure goods in Nile Basin countries, which makes it difficult to export.

(4) Lack of Egyptian banks branches in Nile Basin countries, in addition to mechanisms, to guarantee and finance exports. ${ }^{18}$

2- Obstacles related to the Nile basin Countries

(1) High rates of commercial and non-commercial risks, with the absence of short-term credit facilities (less than 60 days). In addition to the scarcity of foreign currencies in some of these countries. ${ }^{19}$

(2) The high cost of insurance for the exported products at a time, in addition to the cost of internal transportation, as deficiencies in the railways.

(3) The similarity of the production structures of Nile Basin countries.

(4) Lack of basic information on those markets. ${ }^{20}$

\section{C-Opportunities}

The most attractive opportunities and areas of comparative advantage between Egypt and the Nile Basin countries are represented in the following sectors:

1-The agricultural sector, diversity makes the Nile Basin one of the largest areas eligible for agricultural production. Especially in the tropics, coffee, pineapple, cocoa, and palms, in the savannah regions, watermelons, peanuts, and peppers, in the desert areas, dates and cotton, in the Mediterranean basin Vegetables. ${ }^{21}$

2-Investing in the energy sector due to the availability of strategic minerals in the Nile Basin countries.

3-Air transport, the advantages of air navigation extend to a very wide range, which allows not only the development of trade exchange but also the revitalization of the tourism sector that the Nile Basin countries enjoy.

4-Investing in maritime ports and providing related logistic services that have a great role in managing the foreign trade by facilitating the movement of ships in seaports, which would reduce the costs of transporting goods and reduce the export time. 
5-Investing in managing economic zones and specialized business activities, such as information and communication technology services, financial and educational services, health, and professional services. ${ }^{22}$

D- Threats

1- The focus of Nile Basin countries on their foreign trade with major economic blocs and groups as well as the strong presence of multinational companies and their penetration into the economic activities in it.

2-The competition of Southeast Asian countries for many Egyptian products such as clothes.

3-The control of Lebanese and Indian brokers and trade agents ontrade channels, which means that it is difficult to penetrate those markets.

4-The foreign competition by the United States, France, China, and Russia, in addition to Iran, Turkey, and India, all of which seek to access Africa's wealth, especially its oil resources. In addition to "Chinese investment" that is linked to the major monopolies of China, and focuses on the mining sector and infrastructure. ${ }^{23}$

\section{Sixth: Policies for Activating the Egyptian Trade in the Nile Basin}

\section{A- Macro-Level Policies}

1- Establishing strong bilateral and multilateral relations between Egypt and the Nile Basin countries by increasing the volume of trade exchange, joint investments, and supporting technical cooperation by providing training courses in various fields according to their training needs.

2- Integration and specialization according to the comparative advantage, i.e. Egypt get its imports from the Nile Basin countries instead of the foreign countries, and vice versa. The establishment of the African Free Trade Zone that African countries seek to achieve, lead to change the structure of intra-African trade so that trade increases of all exchanged goods, especially industrial goods that most African countries tend to obtain from the world.

3- Focusing on the most attractive investment opportunities in the Nile Basin countries as an investment in the agricultural sector, the energy sector, and the transportation sector, such as maritime ports and air transport. In addition to investing in education, managing economic 
regions, and specialized business activities, such as ICT services, financial, and health services.

4- Make a partnership for development between Egypt and the Nile Basin countries, and the priority is given to strategic dimensions such as food security and infrastructure, and participation in human capital development.

B- Sector-Wide Policies for Supporting Trade

(1) The Industry Sector

The policies related to this sector are to correct market imbalances, support fair competition, and provide additional resources to support the industry and other sectors. Continuing export orientation and opening up to the Nile Basin countries, through achieving more linkages between industry and export growth, and converting part of the commercial activities into manufacturing activities. The coordination between Egypt and the Nile Basin countries and focusing on joint, complementary, and strategic industries to achieve development through increasing added value and shifting towards knowledge-based products with high technological and knowledge content, reviewing and setting incentives for investment in industry and supporting industrial exports. ${ }^{24}$

(2) The Agricultural Sector

The policies related to this sector are to develop agricultural technology, to encourage regional agricultural cooperation between Egypt and the Nile Basin countries for increasing trade exchange.

(3) The Trade Sector

The policies related to this sector are to facilitate customs procedures in light of the African Free Trade Zone, focus on the advantages and preferences of the Nile Basin products, and adopt a risk management system. In addition to increasing export subsidies, link export incentives to valueadded, activate service support programs for export and promote Egyptian products in the Nile Basin countries through granting support for participation in external exhibitions and promotional missions. Establish logistic and storage centers for Egyptian products in the Nile Basin markets, and improve mechanisms for providing information to all exporters on the advantages granted in those markets. ${ }^{25}$

(4) Communications and Information Technology Sector

The policies related to this sector are to merge information technology in the various economic sectors to increase the efficiency and productivity of these sectors, open new markets for the information technology industry and the electronics industry, support its exports to the Nile Basin countries, 
and maximize the benefit of existing trade agreements with those countries to support the information technology industry and increasing joint investments.

(5) The transport sector

The policies related to this sector are to encourage river transport and link it between Egypt and the Nile Basin countries, enhance the vital role of maritime transport, strengthen the road and rail link between Egypt and the Nile Basin countries, and provide facilities, services, and opportunities for this sector.

(6) The banking sector

The policies related to this sector are to activate the role of the Export Development Bank and the Egyptian Company for Guarantee and Financing Exports and expand services in export risks in the Nile Basin countries. ${ }^{26}$

\section{Conclusion}

The results indicate that there is a positive relationship between the gross domestic product of Egypt and the Nile Basin countries with the trade intensity index between Egypt and the Nile Basin countries. The GDP per capita of Egypt and the Nile Basin countries also affect positively the trade intensity index, in addition to the effect of Egypt's trade to the Nile Basin countries on the trade intensity index is positive and significant, so increase Egypt's trade to the Nile Basin countries by one unit leads to increase the trade intensity index by 2.51 units. This may reflect the importance of Egypt's trade to the Nile Basin countries on the trade intensity index between Egypt and the Nile Basin countries.

The study concludes that there is a gap between the actual trade between Egypt and the Nile Basin countries and the hopes placed on it, and for reducing this gap requires more efforts. The intra-trade must be supported and strengthened through the development of infrastructure in the fields of transportation, energy, communications, and information technology, as well as increased coordination between Nile Basin Countries to unify the regulations and rules governing the movement of trade.

Achieving the economic development in Egypt and the Nile basin countries must be based on their resources, whether in terms of investment, awareness, or capacity development, and translating it into effective policies that benefit the countries of the Nile Basin as a whole, including Egypt, by preparing strategies capable of linking a vision Egypt 2030 with Africa Development Plan 2063. 
Analysis of Trade Relations between Egypt and the Nile Basin Countries Using the Gravity Model...... Dr. Sally Mohamed Farid Mahmoud

\section{Endnotes}

${ }^{1}$ Marchand, Marianne H. et al. (1999). The Political Economy of New Regionalisms, Third World Quarterly, Vol 20, No. 5, P.50.

2 Jovanović, Miroslav N. (1998). International Economic Integration: Limits and Prospects, New York, Routledge, P.135.

3 Pomfret, Richard (1997). The Economics of Regional Trading Arrangements Oxford, Clarendon Press, P.80.

${ }^{4}$ Shaw, Timothy M . (1995). Globalization Regionalism and the South in the 1990:

Towards a New Political Economy of Development, the European Journal of Development, London, Frank Cass, Vol 7, No.2, P.257.

5 Robson, Peter (1998). The Economics of International Integration, New York, Roultledge, Fourth Edition, P.68.

${ }^{6}$ Lahham, Dr. Nisreen, Dr. Mohamed Saleh, Sahar Sayed Sabry (2011). Egypt's Water Security \& Future Vision 2030, Center for Future Studies, Egyptian Cabinet's Information and Decision Support Center (IDSC), P.34.

${ }^{7}$ Ezzat, Manar and Wafaa Abd Elkrim (2013). The Economic Resources Available for Economic Development in the Nile Basin and the Extent of the Possibility of Joint Cooperation between Them, Agriculture Research Center, Agriculture Economics Research Institute, Cairo, P. 27.

${ }^{8}$ Abd Eltawab, Mohamed Mehana (2016). Economics of Foreign Trade between Egypt and the Nile Basin Countries, Economics Research Institute, Kafr Elshikh University, P.49.

${ }^{9}$ Hanink, Dean M. \& J. Henry Owusu, (1998). Has ECOWAS Promoted Trade Among Its Members? Journal of African Economies, Oxford Academic, Vol 7, Issue 3, October, P.363.

${ }^{10}$ Oramah, B. O. \& Abau Lehaf, C. (1998). Commodity Composition of African Trade and Intra - African Trade, Journal of African Economies, Vol. 7, No. 2, London, P. 201.

${ }^{11}$ Collier, Paul and Willem Gunning (2005). Trade Policy and Regional Integration: Implications for the Relation between Europe and Africa, London, Vol.18 No, 19, P. 84.

${ }^{12}$ Foroutan, Faezeh and Lant Pritchett (1993). Intra-Sub-Saharan African Trade: Is it too Little?, the World Bank Policy Research, Working paper No.1225, Washington D.C, P. 269.

${ }^{13}$ Egyptian Cabinet, Sustainable Development Strategy, Egypt Vision 2030 ${ }^{14}$ Ibid. www.cabinet.gov.eg/Arabic/GovernmentStrategy/Pages/Egypt'sVision2030.aspx

${ }^{15}$ United Nations Development Program (2018). African Economic Outlook 2018, Regional Development and Spatial Inclusion, New York, UNDP, P. 70. 
${ }^{16}$ United Nations Conference on Trade and Development (2018). World Investment Report 2018, New York and Geneva, United Nations, P. 129.

${ }^{17}$ Jonas, Simon (2014). From Conflict to Cooperation in The Nile Basin, Institute of Technology Zurich, Swiss Federal, P. 21.

18 Abdel Sitar, Mohamed Kareem (2011). Political, Technical and Economical Contexts of the Government of Egypt's Approaches Towards the Nile Basin Countries, School of Global Affairs and Public Policy, AUC University, P. 35.

${ }^{19}$ The World Bank (2018). African Regional Economic outlook Report، Washington D.C, P. 118.

${ }^{20}$ Yaekob, Mekuria Abawari (2011). Conflict and Cooperation among the Nile Basin Countries with Special Emphasis on the Nile Basin Initiative (NBI), International Institute of Social Studies, Erasmus University Rotterdam, Netherlands, P. 37.

${ }^{21}$ United Nations Conference on Trade and Development, op.cit., P. 141.

${ }^{22}$ Reynolds, Edward (2017). Focus on Africa, World History Perspectives, New York, P.52.

23 Melo, Jaime de and Yvonne Tsikata (2014). Regional Integration in Africa Challenges and prospects, WIDER Working Paper 2014/037, World Institute for Development Economics Research, United Nations University, Finland, 2 February, P. 13.

${ }^{24}$ Egyptian Cabinet, Op.cit.

${ }^{25}$ Ibid.

www.cabinet.gov.eg/Arabic/GovernmentStrategy/Pages/Egypt'sVision2030.aspx

${ }^{26}$ Idem.

\section{References}

Abd Elsitar, Mohamed Kareem (2011). Political, Technical and Economical Contexts of the Government of Egypt's Approaches Towards the Nile Basin Countries, School of Global Affairs and Public Policy, AUC University.

Abd Eltawab, Mohamed Mehana (2016). Economics of Foreign Trade between Egypt and the Nile Basin Countries, Economics Research Institute, Kafr Elshikh University.

Central Agency for Public Mobilization \& Statistics (2018). Annual Bulletin of Trade Exchange between Egypt \& Nile Basin Countries 2017, CAPMAS, October.

Central Agency for Public Mobilization and Statistics Database, CAPMAS https://www.capmas.gov.eg, Statistics of UNCTAD Website http://unctadstat.unctad.org/EN, World Bank Database www.worldbank.org 
Analysis of Trade Relations between Egypt and the Nile Basin Countries Using the Gravity Model...... Dr. Sally Mohamed Farid Mahmoud

Collier, Paul and Willem Gunning (2005). Trade Policy and Regional Integration: Implications for the Relation between Europe and Africa, London, Vol.18 No, 19.

Egyptian Cabinet, Sustainable Development Strategy, Egypt Vision 2030 www.cabinet.gov.eg/Arabic/GovernmentStrategy/Pages/Egypt'sVision2030.aspx

Ezzat, Manar and Wafaa Abd Elkrim (2013). The Economic Resources Available for Economic Development in the Nile Basin and the Extent of the Possibility of Joint Cooperation between Them, Agriculture Research Center, Agriculture Economics Research Institute, Cairo.

Foroutan, Faezeh and Lant Pritchett (1993). Intra-Sub-Saharan African Trade: Is It Too Little?, the World Bank Policy Research, Working paper No.1225, Washington D.C.

Hanink, Dean M. \& J. Henry Owusu, (1998). Has ECOWAS Promoted Trade Among Its Members? Journal of African Economies, Oxford Academic, Vol 7, Issue 3, October.

Jonas, Simon (2014). From Conflict to Cooperation in The Nile Basin, Institute of Technology Zurich, Swiss Federal.

Jovanović, Miroslav N. (1998). International Economic Integration: Limits and Prospects, New York, Routledge.

Lahham, Dr. Nisreen, Dr. Mohamed Saleh, Sahar Sayed Sabry (2011). Egypt's Water Security \& Future Vision 2030, Center for Future Studies, Egyptian Cabinet's Information and Decision Support Center (IDSC).

Marchand, Marianne H. et al. (1999). The Political Economy of New Regionalisms , Third World Quarterly, Vol 20, No. 5.

Melo, Jaime de and Yvonne Tsikata (2014). Regional Integration in Africa Challenges and prospects, WIDER Working Paper 2014/037, World Institute for Development Economics Research, United Nations University, Finland, 2 February.

Oramah, B. O. \& Abau Lehaf, C. (1998). Commodity Composition of African Trade and Intra - African Trade, Journal of African Economies, Vol. 7, No. 2, London.

Pomfret, Richard (1997). The Economics of Regional Trading Arrangements Oxford, Clarendon Press.

Reynolds, Edward (2017). Focus on Africa, World History Perspectives, New York.

Robson, Peter (1998). The Economics of International Integration, New York, Roultledge, Fourth Edition. 
Shaw, Timothy M . (1995). Globalization Regionalism and the South in the 1990: Towards a New Political Economy of Development, the European Journal of Development, London, Frank Cass, Vol 7, No.2.

United Nations Conference on Trade and Development (2018). World Investment Report 2018, New York and Geneva, United Nations.

United Nations Development Program (2018). African Economic Outlook 2018, Regional Development and Spatial Inclusion, New York.

The World Bank (2018). African Regional Economic outlook Report، Washington D.C.

Yaekob, Mekuria Abawari (2011). Conflict and Cooperation among the Nile Basin Countries with Special Emphasis on the Nile Basin Initiative (NBI), International Institute of Social Studies, Erasmus University Rotterdam, Netherlands. 